\title{
IMPLEMENTASI PENDEKATAN KONSTRUKTIVISTIK PADA PEMBELAJARAN SAINS DI SMP NEGERI 34 MAKASSAR SULAWESI SELATAN
}

\author{
Subaedah
}

Universi tas M uslim Indonesia, M akassar

\begin{abstract}
ABSTRAK
Penelitian ini bertujuan untuk mengetahui perbedaan pendekatan konstruktivistik dan pendekatan konvensional terhadap: 1) kemampuan pemahaman dan penerapan konsep sains; 2) minat belajar sains; dan 3) kinerja ilmiah dalam bidang sains. Penelitian ini merupakan penelitian eksperimen kuasi dengan variabel bebas pendekatan konstruktivistik dan pendekatan konvensional, dan variabel terikat meliputi kemampuan pemahaman dan penerapan konsep sains, minat belajarn sains, dan kinerja ilmiah sains. Populasi dalam penelitian ini adalah siswa SM P N egeri $34 \mathrm{M}$ akassar, sebagai sampel siswa kelas $\mathrm{VII}_{2}$ dan kelas $\mathrm{VII}_{5}$ yang dipilih secara acak. Desain eksperimen yang digunakan pada kelompok eksperimen dan kelompok kontrol adalah randomized control-group pretest-posttest Design. Hasil analisis deskriptif menunjukkan ada perbedaan yang signifikan pada kemampuan pemahaman dan penerapan konsep sains antara siswa kelas ekperimen dengan pendekatan konstruktivistik dan kelas kontrol dengan pendekatan konvensional, kelas eksperimen dengan nilai mean $=79.69$, kelas kontrol dengan nilai mean $=43.23$. A da perbedaan yang signifikan pada minat belajar sains siswa kelas eksperimen dengan pendekatan konstruktivistik dan siswa kelas kontrol dengan pendekatan konvensional, kelas eksperimen diperoleh nilai mean $=93.97$, kelas kontrol diperoleh nilai mean $=79.03$. Ada perbedaan yang signifikan pada kinerja ilmiah sains antara kelas dengan pendekatan konstruktivistik dan kelas kontrol dengan pendekatan konvensional, kelas eksperimen diperoleh nilai mean = 85.94 , kelas kontrol diperoleh nilai mean $=66.09$. Hasil perhitungan disimpulkan bahwa ada perbedaan yang signifikan pada kemampuan pemahaman dan penerapan konsep sains, minat belajar sains, dan kinerja ilmiah sains antara siswa yang diberi pendekatan konstruktivistik dengan siswa yang diberi pendekatan konvensional.
\end{abstract}

Kata kunci: Pendekatan konstruktivistik, pemahaman dan penerapan konsep, minat belajar, dan kinerja ilmiah sains siswa.

\section{PENDAHULUAN}

Sains (science) atau ilmu pengetahuan alam merupakan ilmu yang mempelajari alam sekitar dan menyibak misteri yang ada didalamnya secara sistematis. Pendidikan sains yang menekankan pada pemberian pengalaman secara langsung, berkaitan dengan cara mencari tahu dan memahami alam sekitar dan makhluk hidup, serta dapat dijadikan sebagai prospek pengembangan ilmu pengetahuan dalam memperoleh pemahaman yang lebih mendalam. Walaupun pada dasarnya materi sains masih dianggap sebagai sesuatu yang abstrak dan rumit.

Materi sains yang abstrak dan rumit menjadikan siswa kurang memahami dan menerapkan konsep sains, menurunkan minat belajar sains, serta tidak memunculkan kinerja ilmiah sains siswa. Di samping itu, proses pembelajaran sains yang masih berpusat pada guru dengan implementasi pendekatan konvensional, semakin menimbulkan persepsi siswa bahwa pelajaran sains adalah materi abstrak, rumit dan membosankan. Fakta yang terungkap di Sulawesi Selatan tahun ajaran 2012-2015 ketidaklulusan siswa 
dipengaruhi oleh rendahnya nilai Sains, bahasa Indonesia, beberapa sekolah unggulan hanya meluluskan siswa sebanyak 43 dari 221 siswa, kelulusan hanya berkisar $19 \%$ saja. Hal ini tentu tidak lepas dari kondisi pembelajaran yang belum menyentuh dimensi siswa itu sendiri.

Salah satu penyebab belum tersentuhnya dimensi siswa dalam pembelajaran sains adalah proses pembelajaran yang masih didominasi pendekatan konvesional dengan metode ceramah sebagai pilihan utama guru, suasana kelas cenderung teacher-centered sehingga siswa menjadi pasif dan tidak mengerti akan materi pelajaran yang disajikan terutama materi sains yang memang dianggap abstrak, sulit dan membosankan. Oleh karena itu, dalam menjadikan materi sains yang abstrak menjadi konkrit, sulit menjadi mudah, membosankan menjadi menyenangkan perlu suatu perubahan proses pembelajaran yang tidak berorientasi pada pendekatan konvensional dengan metode ceramah, akan tetapi sebuah pendekatan pembelajaran yang lebih memberdayakan dan mendorong siswa membangun pengetahuan sendiri dengan mengaitkan pada pengalaman dalam kehidupan seharihari sehingga dapat menemukan pengetahuan sendiri.

Pendekatan pembelajaran yang mengkonstruksi pengetahuan siswa merupakan inovasi pembelajaran yang mengubah paradigma lama (konvensional) menjadi paradigma baru yakni pendekatan pembelajaran konstruktivistik yang dapat mengembangkan dan menggali pengetahuan siswa secara kongkrit dan mandiri, terutama dalam menggali pengetahuan siswa dalam bidang Sains. Dengan Pendekatan konstruktivistik suasana pembelajaran akan berubah menjadi student centered, karena pendekatan ini adalah pendekatan pembelajaran yang menjadikan siswa aktif dalam berfikir dengan membangun pikiran siswa lewat potensi pengetahuan dan pengalaman yang dimiliki.

Dengan demikian diharapkan implementasi model pembelajaran yang ditawarkan pendekatan konstruktivistik dapat meningkatkan pemahaman dan penerapan konsep sains, menarik minat belajar sains, dan dapat memunculkan kinerja ilmiah siswa yang berdampak pada prestasi belajar siswa pada mata pelajaran sains. Adapun implementasi pendekatan konstruktivistik dalam penelitian ini berpijak pada konstruktivistik Piagetian dan V ygotskyan.

\section{KAJIAN TEORI}

\section{Pengertian Hakikat Sains}

B eberapa hal yang perlu diperhatikan dalam mengetahui hakikat sains sehingga sains dapat dipahami dalam perspektif yang lebih luas yaitu: 1) Sains merupakan kumpulan pengetahuan yang berupa fakta, konsep, teori, dan generalisasi yang menjelaskan tentang alam, 2) Sains merupakan suatu proses penelusuran "investigation" yang merupakan pandangan sains yang menghubungkan pengetahuan dengan kegiatan laboratorium, 3) Sains merupakan value atau nilai yang meliputi kejujuran, rasa ingin tahu, dan keterbukaan dalam menyibak berbagai fenomena alam semesta.

Dengan ulasan diatas maka hakikat sains meliputi empat aspek pokok yaitu: 1) Sikap: rasa ingin tahu tentang benda, fenomena alam, makhluk hidup, serta hubungan sebab akibat yang menimbulkan masalah kemudian dipecahkan melalui prosedur dimana sains bersifat open ended, 2) Proses: prosedur pemecahan masalah melalui metode ilmiah yang meliputi penyusunan hipotesis, eksperimen, evaluasi, pengukuran, dan menarik kesimpulan, 3) Produk: berupa fakta, prinsip, teori dan hukum, 4) Aplikasi: penerapan metode ilmiah dan konsep sains dalam kehidupan sehari-hari. 
Pendidikan Sains
Pendidikan Sains menekankan
pada pemberian pengalaman secara langsung, karena itu siswa perlu dibantu untuk mengembangkan potensi kognitif melalui sejumlah keterampilan proses agar mampu menjelajahi, memahami, menguak misteri alam secara ilmiah. Pendidikan sains diarahkan untuk berbuat dan menemukan dalam konsep cooperative learning dan eksperimen, sehingga dapat membantu siswa dalam belajar tuntas dengan pemahaman yang lebih mendalam tentang alam sekitar, mampu memecahan masalah yang teridentefikasi, dan dapat menerapkan sains demi menjaga kelestarian lingkungan. Pemahaman dan penerapan konsep-konsep sains di sekolah dapat melalui kegiatan belajar aktif (active learning) dan belajar langsung (learning by doing) dalam model kooperatif dengan berpijak pada pendekatan konstruktivistik.

Jadi pendidikan sains merupakan upaya mempersiapkan siswa untuk melek sains, memahami dirinya dan lingkungan sekitar, melalui pengembangan keterampilan proses, sikap ilmiah, keterampilan berpikir, penguasaan konsep sains yang esensial, dalam upaya pengelolaan lingkungan secara bijaksana yang dapat menumbuhkan sikap pengangungan terhadap A llah.

\section{Prinsip Pembelajaran Sains}

Dari pemahaman dan penerapan konsep sains muncul prinsip pembelajaran sains yang pada proses belajar mengajar sangat memperhatikan karakteristik sains sebagai proses dan sains sebagai produk. Sains sebagai proses adalah prosedur pemecahan masalah dengan metode ilmiah, yang meliputi penyusunan hipotesis, rancangan eksperimen, evaluasi, pengukuran dan penarikan kesimpulan. Sains sebagai produk meliputi fakta, prinsip, teori, dan hukum. Dari prinsip sains guru dalam proses pembelajaran harus memiliki kompetensi agar dapat mengimplemetasikan sains secara optimal. Sebagaimana yang telah ditetapkan dalam
UU pendidikan nomor 14 tahun 2005, juga terdapat dalam Standar $\mathrm{N}$ asional Pendidikan (PP. Nomor 19 tahun 2005).

\section{Hasil Belajar Sains}

Tujuan pembelajaran berkaitan dengan hasil belajar yang senantiasa mengacu pada 3 jenis domain (ranah) yang melekat pada diri siswa, yaitu: 1) ranah proses berpikir (cognitive domain); 2) ranah sikap (affective domain); 3) ranah keterampilan atau kinerja ilmiah (psychomotor domain), dalam konteks evaluasi hasil belajar ketiga domain itulah yang dijadikan sasaran dalam setiap kegiatan evaluasi hasil belajar.

Penilaian hasil evaluasi belajar untuk melihat prestasi siswa dilakukan pada awal, proses pembelajaran dan akhir pembelajaran dengan menggunakan tes tertulis (pemahaman dan penerapan konsep sains), skala sikap (minat belajar sains), dan pengamatan (kinerja ilmiah sains), hasil penilaian diwujudkan dalam bentuk nilai dengan ukuran kuantitatif dan dalam bentuk deskriptif kualitatif

Penilaian yang dilakukan dalam penelitian ini adalah terhadap: 1) Pemahaman dan penerapan konsep sains, 2) $M$ inat belajar sains, 3) K inerja ilmiah sains.

\section{Pendekatan Konstruktivistik pada Pembelajaran Sains}

a. Pengertian konstruktivistik

Konstruktivistik merupakan aliran dalam filsafat, dikemukakan oleh Giambastita Vico lahir 23 Juli 1668 di Naples, Itali, meyakini bahwa manusia dikarunia kemampuan untuk mengkonstruk pengetahuan setelah berintraksi dengan lingkungan, Menurut Bruner (2014: http://www.TIP. H Htm) konstruktivistik adalah suatu proses pembelajaran di mana siswa mengkonstruk idea baru berasaskan pada pengetahuan yang ada, menguji konsep dan mengintepretasikan pengetahuan, mengaplikasikan pada lingkungan, 
membuat hipotesis dan keputusan yang melibatkan pemikiran matang yang berasal dari dalam diri (potensi kognitif), memberikan makna dan pembentukan pengalaman, serta mengembangkan pengetahuan yang diberikan (Beyond the information given) sesuai dengan kadar intelektual yang dimiliki $\mathrm{H}$ asil pendekatan ini dapat ditemui pada discovery learning.

\section{b. Prinsip pendekatan konstruktivistik Prinsip dasar yang melandasi pembelajaran konstruktivistik adalah semua pengetahuan dikonstruk (dibangun)}

Tabel 1

Prinsip Pembelajaran K onstruktivistik

\begin{tabular}{|c|c|}
\hline Aspek teori belajar & konstruktivistik \\
\hline $\begin{array}{l}\text { Bagaimana terjadinya } \\
\text { belajar }\end{array}$ & $\begin{array}{l}\text { B elajar adalah menciptakan makna dari pengalaman. } \\
\text { Otak menyaring input dari dunia luar untuk menghasilkan realitas } \\
\text { dunia itu sendiri. } \\
\text { Siswa membangun interpretasi personal terhadap dunia luar } \\
\text { berdasarkan atas pengalaman individual dan interaksi dengan } \\
\text { lingkungan }\end{array}$ \\
\hline $\begin{array}{l}\text { Bagaimana terjadinya } \\
\text { belajar }\end{array}$ & $\begin{array}{l}\text { Siswa dan lingkungan saling berintraksi dalam menciptakan makna. } \\
\text { Pentingya konteks, isi pengetahuan harus dipasangkan dengan } \\
\text { situasi dimana pengetahuan itu terjadi. } \\
\text { B elajar terjadi dalam seting yang realistis } \\
\text { B elajar harus terdiri dari aktivitas, konsep dan budaya. }\end{array}$ \\
\hline $\begin{array}{l}\text { A pakah peran } \\
\text { memori }\end{array}$ & $\begin{array}{l}\text { M emori selalu dijadikan sebuah bangun sebagai kumulatif dari } \\
\text { sejarah interaksi. } \\
\text { M enekankan pada kefleksibelan pengguna pengetahuan, } \\
\text { pengetahuan yang sudah ada terlebih dahulu daripada mengingat } \\
\text { kembali skema yang sudah ada. } \\
\text { Siswa menciptakan sesuatu yang baru dan memahami situasi } \\
\text { tertentu dengan mamadukan pengetahuan utama dari sumber } \\
\text { berbeda yang sesuai untuk problem yang dihadapi. }\end{array}$ \\
\hline $\begin{array}{l}\text { Bagaimana terjadinya } \\
\text { teransfer }\end{array}$ & $\begin{array}{l}\text { Teransfer ilmu difasilitasi oleh lingkungan dalam tugas autentik } \\
\text { yang diletakkan dalam konteks yang bermakna. } \\
\text { Pemahaman ditunjukkan oleh pengalaman dan keautentikan } \\
\text { pengalaman penting untuk kemampuan pengguna ide-ide. } \\
\text { Kesesuaian dan keautentikan pengguna berasal dari kemampuan } \\
\text { siswa secara aktual menggunakan pengetahuan dalam situasi riil. }\end{array}$ \\
\hline $\begin{array}{l}\text { A pakah asumsi dasar } \\
\text { atau prinsip-prinsip } \\
\text { yang relevan dengan } \\
\text { desain pembelajaran }\end{array}$ & $\begin{array}{l}\text { M enekankan pada konteks dimana keterampilan akan dipelajari dan } \\
\text { diaplikasikan, menempatkan belajar dalam konteks yang bermakna } \\
\text { Siswa mengontrol dan memanipulasi informasi } \\
\text { M enghadirkan informasi dalam berbagai macam cara (fleksibilitas } \\
\text { kognitif } \\
\text { M endukung pemecahan problem yang membuat siswa dapat } \\
\text { menerapkan informasi } \\
\text { Waktu belajar kognitif, belajar kolaboratif, negosiasi sosial. }\end{array}$ \\
\hline $\begin{array}{l}\text { Bagaimana } \\
\text { seharusnya } \\
\text { pembelajaran disusun }\end{array}$ & $\begin{array}{l}\text { M embangun model pengetahuan, meningkatkan kerja sama, } \\
\text { mendesain lingkungan yang autentik }\end{array}$ \\
\hline Peran guru & \\
\hline
\end{tabular}

dari diri dan pikiran manusia bukan dipersepsi secara langsung oleh indra, konstruktivistik berakar pada asumsi bahwa pengetahuan terbentuk di dalam otak manusia, dan subjek yang berfikir tidak memiliki alternatif selain mengkostruk apa saja yang diketahui berdasarkan pengalaman sendiri, Daniel Muijs (2013: 98). Adapun prinsip pembelajaran konstruktivistik dapat dilihat dalam tabel 1.

.




\begin{tabular}{|l|l|}
\hline Aspek teori belajar & \multicolumn{1}{|c|}{ konstruktivistik } \\
\hline & $\begin{array}{l}\text { secara efektif memonitor dan selalu memperbaharui bangunan } \\
\text { pengetahuan mereka } \\
\text { M engarahkan dan mendesain pengalaman bagi siswa sehingga, } \\
\\
\text { autentik, konteks yang relevan dapat dialami }\end{array}$ \\
\hline Tujuan pembelajaran $\begin{array}{l}\text { Siswa membangun sendiri pengetahuannya lewat potensi yang } \\
\text { dimiliki }\end{array}$ \\
\hline
\end{tabular}

\section{METODE PENELITIAN}

J enis penelitian adalah penelitian kuantitatif dengan menggunakan metode eksperimen kuasi (quasi eksperimental research). M enurut K erlinger, (2004:508) metode eksperimen kuasi menunjukkan secara tajam suatu hubungan sebab akibat, apakah penggunaan pendekatan konstruktivistik mengakibatkan peningkatan kemampuan kognitif siswa sehingga menghasilkan nilai evalusi belajar yang baik.

Desain penelitian menggunakan random untuk memilih anggota kelompok eksperimen dan kelompok kontrol. Rancangan penelitian menggunakan desain pre-test post-test dengan kelompok nonekuivalen (non equivalent control group design). Adapun rancangan dapat dilihat dalam diagram rancangan pembelajaran pada Gambar 1.

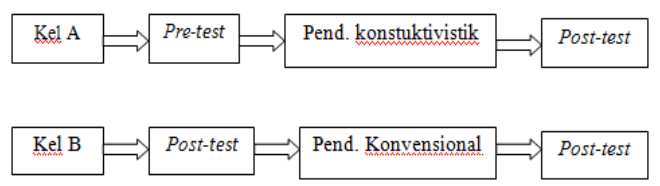

Gambar 1

Diagram Rancangan pembelajaran dengan menggunakan Design Pre-test post-test (Non Equivalent Control Group Design)

K eterangan:

A: Kelompok eksperimen dengan treatment pendekatan konstruktivistik dalam pengembangan kognitif siswa.

B: Kelompok kontrol dengan treatment pendekatan konvensional dalam pengembangan kognitif siswa.

$$
\text { Dalam penentuan sampel }
$$

dipergunakan randomized control group pre-test post-test design. Pengambilan sampel dilakukan secara acak pada siswa kelas populasi yang terdiri dari 7 kelas populasi, dan diambil 2 kelas subjek. Keseluruhan siswa kelas populasi diasumsikan memiliki prestasi belajar sains yang sama berdasarkan hasil nilai raport semester ganjil tahun pelajaran 2014-2015. selanjutnya dilakukan pre-test post-tes sebelum dan sesudah treatment, pemberian pre-test post-test dilakukan dengan pengontrolan dan pengendalian pada variabel yang berhubungan dengan validitas internal dan eksternal.

$\checkmark$ ariabel penelitian terdiri dari variabel bebas varibel terikat, dan variabel kontrol. Variabel bebas meliputi pendekatan konstruktivistik dan pendekatan konvensional, variable terikat meliputi hasil evaluasi belajar yang dinilai dari pemahaman dan penerapan konsep sains, minat belajar sains, dan kinerja ilmiah sains sains, sedangkan pada varibel control meliputi guru materi pelajaran, dan lama (waktu) pelajaran.

Teknik analisis data yang digunakan adalah menghitung perbedaan antara hasil pre test dan post test untuk masing-masing kelompok, sehingga ( $\left.T_{\text {2eksperimen }}-T_{\text {1eksperimen }}\right)$ dan $\left(T_{2 \text { kontrol }} T_{1 \text { kontrol }}\right)$. kemudian membandingkan perbedaan tersebut. Dalam menentukan apakah penerapan perlakuan $X$ berkaitan dengan perubahan yang besar pada kelompok eksperimen, maka dihitung ( $\left.T_{\text {2eksperimen }}-T_{\text {leksperimen }}\right)$ $\left(T_{2 \text { kontrol }}-T_{1 \text { kontrol }}\right)$. Teknik analisis data berdistribusi normal digunakan uji $t$ saling bebas (independent sample t-test) dengan analisis data menggunakan program SPSS for windows 15. 


\section{HASIL DAN PEMBAHASAN}

\section{Hasil Penelitian}

Berdasarkan analisis data maka diketahui ada perbedaan kemampuan pemahaman dan penerapan konsep sains, minat belajar sains, dan kinerja ilmiah sains siswa antara siswa kelas eksperimen dengan pendekatan konstruktivistik dan siswa kelas kontrol dengan pendekatan konvensional. Deskripsi data dapat dilihat pada Tabel 2.

Tabel 2

Rangkuman D eskripsi Data Post-Test

K emampuan Pemahaman dan Penerapan K onsep Sains, M inat B elajar Sains dan Kinerja IImiah dalam Bidang Sains

\begin{tabular}{|c|c|c|c|c|c|c|}
\hline \multirow{3}{*}{ Perolehan } & \multicolumn{6}{|c|}{ Hasil Belajar Sains } \\
\hline & \multicolumn{2}{|c|}{$\begin{array}{c}\text { Pemahaman dan } \\
\text { Penerapan konsep } \\
\text { Sains }\end{array}$} & \multicolumn{2}{|c|}{ Minat Belajar Sains } & \multicolumn{2}{|c|}{ Kinerja Ilmiah } \\
\hline & Eksperimen & kontrol & Eksperimen & kontrol & Eksperimen & kontrol \\
\hline$N$ & 35 & 35 & 35 & 35 & 35 & 35 \\
\hline Mean & 79.69 & 43.23 & 93.97 & 79.03 & 85.94 & 66.09 \\
\hline Median & 80 & 45 & 95 & 79 & 86 & 66 \\
\hline Std. Deviation & 14.313 & 15.131 & 12.814 & 13.085 & 7.658 & 10.467 \\
\hline Minimum & 50 & 15 & 65 & 55 & 75 & 45 \\
\hline Махітит & 102 & 65 & 120 & 110 & 99 & 88 \\
\hline
\end{tabular}

Dengan melihat tabel 2 dengan skor rata-rata perolehan kelas eksperimen pada pemahaman dan penerapan konsep sains dengan mean $=79.69$, minat belajar sains dengan mean $=93.97$, dan kinerja ilmiah sains siswa dengan mean $=85.94$, sedang kelas kontrol pada pemahaman dan penerapan konsep sains dengan mean $=$ 43.23, minat belajar saians dengan mean $=$ 79.03, dan kinerja ilmiah sains siswa dengan mean 66.09, maka dikatakan bahwa, kelas eksperimen dengan pendekatan konstruktivistik lebih tinggi pemahaman dan penerapan konsep sains, minat belajar sains, dan kinerja ilmiah sains siswa dibanding dengan kelas kontrol dengan pendekatan konvensional. A pabila digambarkan tingkat prestasi belajar siswa kelas eksperimen dan kelas kontrol dalam sebuah histogram maka dapat dilihat pada gambar 2.

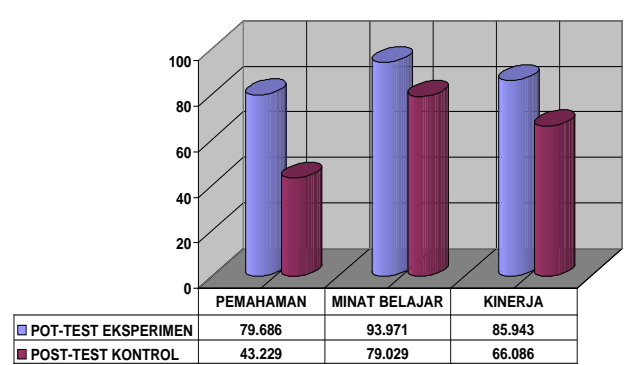

Gambar 2

Histogram Skor Post-Test Siswa terhadap Prestasi B elajar Sains pada Siswa kelas eksperimen dan kelas kontrol

\section{Pembahasan}

Hasil penelitian yang dianalisis dengan t-test dideskripsikan bahwa hasil pengujian hipotesis menunjukkan peningkatan pemahaman dan penerapan konsep sains, minat belajar sains, dan kinerja ilmiah sains pada siswa kelas eksperimen dengan pendekatan konstruktivistik dibanding siswa kelas kontrol dengan pendekatan konvensional. Adanya perbedaan peningkatan dapat 
dipengaruhi oleh implementasi dua pendekatan berbeda mengakibatkan dua efek yang berbeda. Dengan demikian, dikatakan bahwa pendekatan pembelajaran (instructional aproach) dapat mempengaruhi pemahaman dan penerapan konsep, minat belajar, serta kinerja ilmiah sains siswa sehingga dapat meningkatkan prestasi yang lebih baik.

Implementasi pendekatan konstruktivistik menuntun siswa membuka cakrawala pikir lewat pengalaman dan potensi pengetahuan awal yang dimiliki, misal pada konsep materi membedakan tumbuhan biji monokotil dan dikotil, dengan memperlihatkan objek langsung siswa akan mudah memahami, mengerti bahwa perbedaan monoktil dan dikotil dapat dilihat dari daun, batang bunga dan akar, tanpa pemberitahuan dari guru siswa dapat membangun pengetahuan sendiri lewat pengalaman dan pengamatan.

M engimplementasikan pendekatan konstruktivistik dalam pembelajaran sains lewat pengamatan hasil penelitian dapat mengatasi kejenuhan siswa dalam belajar, dengan memperlihatkan siswa pada objek langsung, mengingatkan kembali pengalaman yang dilalui, dan menjadikan siswa sebagai pusat pembelajaran dapat memusatkan perhatian siswa pada materi pembelajaran, hanya saja yang menjadi salah satu kendala dalam mengimplementasikan pendekatan konstruktivistik adalah realita di Sulawesi Selatan dimana banyak guru yang belum mengetahui beberapa pendekatan pembelajaran termasuk pendekatan konstruktivistik.

Dengan demikian dikatakan bahwa pendekatan konstruktivistik lebih baik dari pendekatan konvensional, karena pendekatan tersebut dapat meningkatkan pemahaman dan penerapan konsep sains siswa, menumbuhkan minat belajar sains siswa, dan memunculkan kinerja ilmiah sains siswa. Namun di Sulawesi Selatan khususnya di SMP Negeri 34 makssar pendekatan konstruktivistik belum diimplementasikan secara optimal disebabkan kurangnya pemahaman guru akan pendekatan konstruktivistik, kurangnya kompetensi guru, kurangnya kesadaran guru untuk melakukan inovasi pembelajaran dan kurang pelatihan guruguru dalam peningkatan pedagogik.

\section{KESIMPULAN}

Dari hasil analisis diperoleh bahwa ada perbedaan tingkat kemampuan pemahaman dan penerapan konsep sains, minat belajar sains, dan kinerja ilmiah sains siswa antara kelas eksperimen dengan pendekatan konstruktivistik dan kelas kontrol dengan pendekatan konvensional. Peningkatan kemampuan pemahaman dan penerapan konsep sains siswa kelas eksperimen sebesar $47.938 \%$ kelas eksperimen turun sebesar $-0.859 \%$, peningkatan minat belajar sains siswa kelas eksperimen sebesar $8.300 \%$ kelas kontrol turun sebesar $-12.909 \%$, peningkatan kinerja ilmiah sains siswa kelas eksperimen sebesar $26.064 \%$ kelas kontrol turun sebesar $1.643 \%$. Hal ini menunjukkan bahwa implementasi pendekatan konstruktivistik pada pembelajaran sains di SM P Negeri 34 pada siswa kelas $\mathrm{VII}_{2}$ dan siswa kelas $\mathrm{VII} 5$ lebih baik dari implementasi pendekatan konvensional.

\section{DAFTAR PUSTAKA}

Bell, Beverly. F. 1993. Children's science, constructivism and learning in science. Australia: Deakin University.

Elby. A. 2012. What students' learning of representations tells us about constructivism. .Physics Department University of Maryland. http://www2. physics.umd.edu/

Glasersfeld, Ernst Von. 1989. An exposition of constructivist why some like it radical. Scientific Reasoning Research Institute. University of $M$ assachusetts. 
Piaget. J. 1969. The child's conception of physical causality. New Jersey: Little Field, A dams \& Co.

Saekhan M uchith, M . 2012. Pembelajaran kontekstual. Semarang: Rasail M edia Group.

Suparno, S. J. 2013. Filsafat konstruktivisme dalam pendidikan. $\mathrm{Y}$ ogyakarta: $\mathrm{K}$ anisius.

Trianto. 2015. Model-model pembelajaran inovatif berorientasi konstruktivistik dengan konsep landasan teoritis praktis dan implementasinya. Jakarta: Prestasi Pustaka. 